\title{
GRAZING SYSTEMS ON DAIRY AND SHEEP FARMS
}

\author{
D. I. GuUE \\ Farm Advisory Officer, Department of Agriculture, \\ Dargaville
}

The pURPose of this paper is to deal with current grazing methods as practised on high-producing dairy and sheep farms. While an attempt will be made to give a general picture of the situation in New Zealand, N orthland experience will be heavily drawn on for several reasons. Northland has given the highest yearly pasture production ever recorded in N ew Zealand; stock are fed almost entirely on pasture, hay or silage; the high development of clay in Northland soils and the high rainfall mean that pasture damage is a constant threat; and, lastly, it is the district in which the writer works and knows best.

\section{DAIRYING}

To increase utilization and decrease waste, rotational grazing is almost universally practised on high-producing dairy farms, but with two main variations - 24-hour grazing, where the cows spend a complete day and night in each paddock, and 12-hour grazing, where they shift to a fresh paddock after each milking.

Rotational grazing, as against set stocking, is based on the fundamental fact that a leniently-grazed pasture produces a much greater bulk of feed in 24 hours than a short pasture. However, as a pasture gets longer, its digestibility decreases. It has been found in practice that feed about 10 in. long represents a suitable compromise between high production and high digestibility, and at this length it is easily handled by the milking cow.

During most of the dairying season, it takes about 20 days for a high-producing pasture of perennial ryegrass and white clover to grow from the post-grazing level to the $10 \mathrm{in}$. level, so the efficient farmer on the 24-hour grazing system uses twenty milking paddocks, round which the herd rotates on a 20-day cycle. Twenty to twenty-five cows per acre are needed to eat each paddock 
out completely in 24 hours - that is, for a 100 cow farm at or slightly above the one cow equivalent per acre mark, twenty milking paddocks are needed, each between 4 and 5 acres in area.

All paddocks should be as nearly as possible identical , in size, as it is noticeable that any which are larger than the rest are very wastefully'grazed. Each paddock should, of course, have an ample supply of good drinking water, and should be served by a double-fenced metalled race.

This system -20 milking paddocks, 24 hours in each paddock, and a grazing pressure of 20 to 25 cows per acre per 24 hours - is the standard pattern on efficiently-run dairy farms all over New Zealand.

It has two advantages. First, it represents a satisfactory compromise between productivity and palatability. Second, pastures are effectively controlled and the need for topping reduced.

One major disadvantage is that the farmer cannot arrange for a system of night paddocks, for convenience in keeping the cows handy to the milking shed overnight. Though night paddocks were treated with scant respect a few years ago, following rising soil fertility, increases in herd numbers and heavier demands on labour, their advantages are now more appreciated by advisers.

The other main system employed is 12-hour grazing, where cows are shifted to a fresh paddock after each milking. The pasture still needs a 20-day spell to regrow to the desirable 10 in. height, so this system requires up to 40 milking paddocks. Furthermore, to clean up a dense 10 in. pasture in 12 hours, a grazing pressure of between 40 and 50 cows per acre is required, that is, for a herd of 100 cows on 100 acres the farmer needs 40 milking paddocks, each from 2 to $21 / 2$ acres in area.

The 12-hour system has several advantages. Cows like it and produce well on it, because they get a fresh paddock after every milking. The farmer likes it because the cows are so keen to get on to this fresh paddock that they will bring themselves to the shed and take themselves back after milking. It also allows for night paddocks, close to the shed or house.

It has also some disadvantages. It demands much more subdivision, and a virtual doubling-up of gateways and water troughs. When cows are anticipating a change of paddock, they will not clean up any. unpalatable feed on the old one. Feed missed the first time is quite rank by next grazing, and if not topped will be avoided for the rest of the season. Changing back to 24-hour grazing 
is not a satisfactory solution, as the cows retaliate by cutting down on milk production. The herd readily accepts a change from 24-hour grazing to 12-hour grazing at any time, but a change in the reverse direction should as a rule be made only at the start of the season, when the cows are still settling down.

In order to keep pastures at the milk-producing stage, the farmer often has to spend much time topping the herbage, which is wasteful of time, machinery and feed.

Twelve-hour grazing gets a bad reputation when it is used on farms that are not sufficiently geared to it where there are not enough paddocks, or the paddocks are too large, for instance - and it is then a most wasteful and inefficient system. However, though it is more expensive, 12-hour grazing is a logical development from, and improvement of, 24-hour grazing, and with rising stocking rates it is becoming more widely used. Properly handled, it is the most efficient grazing method yet developed.

At the start of the season, during a dry summer, and in winter, rotational grazing must be modified to cope with special conditions.

At the start of the season it has been observed that, when cows are first shut in a paddock, they concentrate on feeding for a while, and do very little walking. After a while, they get restless and start moving round, possibly looking for their calves; and that is when pugging starts. Farmers on wet soils put the herd on grass for a period of $1 \frac{1 / 2}{2}$ to 2 hours after the morning milking, and again before the evening milking. Knowing they have only a limited time to graze, the cows make the most of it, concentrate on feeding and do very little walking. When time is up, they are taken off and put on a non-pugging surface, such as a sawdust pad or concrete yard, and given access to good hay or silage. Pasture damage is much re duced, and there is little, if any, lowering of milk production.

In dry summers, the traditional system is to open all gates and give the herd free range, but if the dry spell is prolonged the farm is soon carrying only low-quality feed that has been repeatedly rejected by the cows, and production falls rapidly. A better system is to carry on with rotational grazing but allow the herd two and later three paddocks per grazing, which on a twenty paddock farm still permits a spell of 7 to 10 days between grazing. It is noticeable that adequate water reticulation and good subdivision continue to pay off even in the driest summer. 
Water needs of stock are high in a drought, and good subdivision allows the limited' amount of milking feed to be grazed off without waste, and gives it a chance to regrow.

A few words about winter management. On free-draining soils, cows are moved slowly round the farm in breaks between double electric fences at a stocking rate of up to 200 cows per acre per day. Hay and silage are also fed on the breaks. This is the best system of on-grass wintering where the soil type is suitable, but in' Northland, with the high development of clay in the soil and the high winter rainfall, 200 cows per acre is more like rotaryhoeing than grazing.

Split herd wintering is widely used. This involves spreading the animals round the farm, a few in each paddock. In favourable seasons in Northland, a wintering rate of $1 \frac{1}{2}$ to 2 cows per acre is aimed at, but in wet winters even $3 / 4$ of a cow per acre does excessive pasture damage. As a result there has been a major swing to off-grass wintering. The most efficient is the cow-cubicle method, where cows spend six weeks in a cubicle measuring $7 \mathrm{ft}$ by $3 \mathrm{ft}$, with their tails over-hanging a dunging race. Though the scene inside a cubicle barn is claustrophobic, cows winter so well that the traditional ration of onethird of a bale of hay per cow per day must be reduced to one-quarter or even one-fifth of a bale, to prevent their becoming too fat. Costs of cow cubicles range from $\$ 20$ to $\$ 40$ per cow. Also favoured is the sawdust pad, on which cows are wintered at the rate of 40 sq. ft per cow. $\mathrm{H}$ ay is fed on a concrete strip adjoining the pad. Sawdust pads cost from $\$ 5$ to $\$ 12$ per cow.

\section{SHEEP FARMING}

The usual pattern on high-producing sheep farms is that ewes are spread out from just before lambing until weaning, and again at tupping, and mob-stocked at all other periods of the year.

There are several reasons why rotational grazing has not assumed the paramount importance on sheep farms that it has on dairy farms. It is generally accepted that ewes should have had time to settle down in the paddock before lambing, and that set-stocking ewes with lambs at foot gives better lamb growth. Also, up to now sheep farms have been lower stocked than dairy farms, and efficiency. of pasture production and utilization have not been so important. 
Furthermore, there is not much incentive to make ewes clean out pastures completely as beef cattle can be used to clean up uneaten grass and low quality feed in a way which is not practicable for dairy cows.

With the need to increase carrying capacity and output per labour unit, there has been a marked swing towards more efficient grazing techniques. During the period when the ewes are mob-stocked, grazing management on a heavily stocked sheep farm is now very similar to that on a high-producing dairy farm. In general, there will be at least 18 to 20 paddocks, and a grazing pressure of from 50 to 80 ewes per acre for two or three days, equivalent to a stocking rate of 20 to 25 dairy cows per acre for 24 hours.

There is a trend to double-fenced races, which facilitate stock movement, permit rotational grazing, and reduce pugging. These are nearly as valuable on sheep farms as on dairy farms.

During the autumn, ewes are mob-stocked to deal with rank pasture, and control fern and other weeds. Most worthwhile pasture and weed control is now carried out by ewes and beef cows, at the time of year when their nutrient needs are lightest. Besides being more economic, they have proved much more effective at weed control than the wethers and steers which were formerly used for this purpose.

On wet soils, mob-stocking in winter can cause severe pugging, for, if ewes become accustomed to being shifted every two or three davs. thev over-react and flock to the gate every time the farmer or his dog appears on the skyline. An effective counter is to shift the ewes every day, irrespective of whether they have cleaned up the feed or not, at a set time first thing in the morning. Once they have had their daily shift, ewes ignore the farmer completely, and he can work amongst them without the mental strain of seeing pasture trampled into mud.

Feeding hay to beef cattle in winter is a major cause of pugging. As hay time approaches, cattle give up grazing and congregate, waiting to be fed, and that is when most pasture damage occurs. To obviate this, Northland farmers have copied the split herd wintering of the dairy farmer. Cattle are spread lightly round the farm, and no hay is fed to them at all. This system works well in a district where there is appreciable pasture growth during winter. In passing, because of winter growth, the practice of autumn-saved pasture has gone into abeyance in $\mathrm{N}$ orthland. 
A word about sheep and cattle ratios, which have often been regarded as having the force of Holy Writ in some districts. In the writer's view, the correct ratio for any farm is a fluctuating thing, being determined by such factors as the relative and changing profitability of sheep and cattle, the number of ewes that the farmer and his labour force can lamb and look after, and the degree and stage of development of the farm, particularly the subdivision.

To conclude, there have been few recent breakthroughs in grazing management. Farmers have worked on the principles that stock must be made to do as much of the work as possible, and that they can be trained to work effectively to achieve this. By developing and improving simple management techniques, most of which have been known for years, farmers have shown how to run more stock with greater efficiency, and often with less labour. There is nothing spectacular about these practices; the main thing to be said in their favour is that they work.

\section{DISCUSSION}

Questioned as to whether full utilization of pasture could be obtained on hill country with 24-hour shifts, Glue replied that it demanded adequate subdivision and stocking at the rate of 150 ewes per acre for the 24 hours.

He agreed that more attention should be paid to rotational grazing as a management practice with ewes and lambs at higher levels of fertility and at higher stocking rates. It did not appear likely that under a 20-day spell pastures would become too long and thus lead to wastage through decomposition.

To a comment that there might be a transfer of fertility under the 12 hour grazing system, Glue stated that it was not very likely with 40 paddocks. This was in contrast to the old system of having two to three paddocks near the shed and using them as night paddocks continuously. With 40 paddocks, if any transfer did show up, the paddock could easily be switched to day grazing.

It was suggested that 12- and 24-hour grazing systems should be called block grazing, rather than rotational. To a comment that grazing pressures of 400 to 500 ewes per acre were being used in the Manawatu, Glue replied that this would be far too great for Northland soils. They were working at the 20-cow or 150-ewe level. This could perhaps be increased but not to the level suggested.

Referring to the effect of split-wintering on early spring yields, Glue stated that farmers could run $2 \frac{1}{2}$ cows per acre in a good winter without deleterious effects. However, a bad winter did result in reduced spring growth. He did not favour long pasture as a good milking feed. 